Review Article

\title{
Biochrono and Tectonic Framework for the Origin of KTB Canyon in Nagapattinam Subbasin, Cauvery Basin
}

\author{
B C JAIPRAKASH*, P VENKATESH, MAYA V PANICKER, HARRY GILBERT and SELVIN SHYAM \\ PAUL \\ Regional Geoscience Laboratories, ONGC LTD., RR Towers, 200 Feet Road, Sasthanagar, Villivakkam, \\ Chennai 600 049, India
}

(Received on 15 May 2016; Accepted on 25 June 2016)

\begin{abstract}
There is a prominent canyon feature across Cretaceous - Tertiary boundary (KTB) in the Nagapattinam sub basin. Foraminiferal data from 34 well sections reveal that the sedimentary processes were disrupted 0.5-1 Ma before KTB and 0.5 to 1 Ma post KTB with intervening erosional process. The hiatus across KTB is diachronous and is 7-9 Ma along the axis, 3-4 Ma along the flanks and 1.8 Ma along the periphery and beyond the canyon.

A credible correlation exists between timing of relative sea level fall and KTB canyon formation in the Cauvery Basin and the Deccan volcanism in west central India. The reunion hot mantle plume above which India was gliding over during Late Maastrichtian lifted west, central and peninsular India into a dome like feature. This has caused upliftment and east ward tilt of the Cauvery Basin. Relative sea level fall is recorded on top of the Kallankurichhi Formation in the outcrops (CF6CF5 zones, Phase-1 Deccan volcanism, 70 Ma). Destabilization of shelf edge and slope sediments began around this time. The coastline receded and the areas west of Orathanadu got exposed (CF4 zone; $\sim 68 \mathrm{Ma}$ ). Doming continued till the base of CF3 zone ( $67 \mathrm{Ma}$ ). The critical point of instability was around $\sim 66.4 \mathrm{Ma}$ (CF2-CF1 zones; Phase - 2 Deccan volcanism). This triggered a chain of sedimentary processes involving shelf edge collapse, slumping, sliding and debris flows. Vast amounts of Middle - Late Maastrichtian sediments were removed creating the canyon. Post Deccan volcanism, there was a transgression beginning from P1b planktic zone ( $65 \mathrm{Ma})$ as a response to thermal cooling and subsidence. Thus it is evident that canyon development was largely restrained to upper- middle slope regions within a chronostratigraphic framework of 70-66.4Ma.
\end{abstract}

Keywords: Cauvery Basin; Nagapattinam Sub Basin; KTB Canyon; Foraminifera; Hiatus; Reunion Hot Mantle Plume; Deccan Volcanism

\section{Introduction}

Cauvery Basin is a rift and drift basin which came into existence due to dismemberment of Gondwana land some time in Middle to Late Jurassic times (Rangaraju et. al., 1993, Prabhakar and Zutshi, 1993). Seismic data reveal the presence of sedimentary pile of more than 6-7 Km in the axial part of the sub basins (Venkatarengan et al., 1993). The tectonic framework of the Cauvery Basin consists of NE-SW trending horst-graben architecture (Reddy et al., 2013, Fig. 1B). Extensive exploratory drilling has produced voluminous database on petrography, sedimentology and biostratigraphy. Major unconformities and their correlative conformities punctuate the litho column during Aptian-Albian, Late Turonian, Late Santonian, Late Campanian (Reddy et al., 2013), KTB (Raju et al., 1994; Jaiprakash et al., 1993), Eocene (Keller et al., 2016) and Mio Pliocene. The present work deals with KTB unconformity and associated events in the Nagapattinam sub basin.

The Nagapattinam sub basin is a NE-SW trending low bounded by Mannargudi ridge on the SW, Karaikal ridge on the N-NE and Tirutturaipundi -Vedaranniyam high on the East and SE (Fig. 1). Major hydrocarbon discoveries in the Cauvery Basin have

\footnotetext{
*Authorfor Correspondence: E-mail: jaiprakash_bc@ongc.co.in
} 


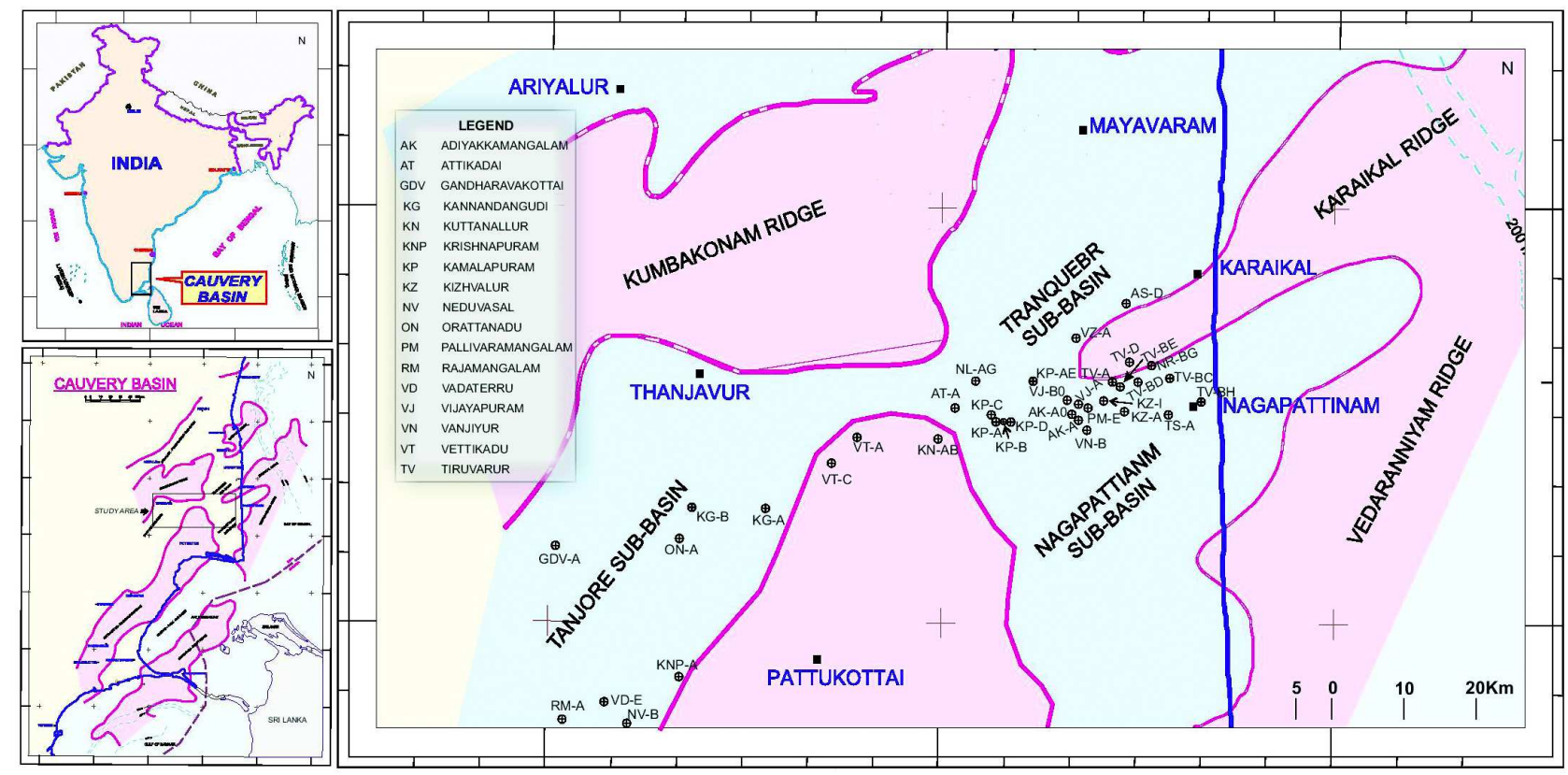

Fig. 1: Location map of Nagapattinam sub-basin showing area of study along with the studied well sections

come from this sub basin and the reservoirs are mostly aligned along the canyon trend. The present study was undertaken:1) to estimate relative sea level changes during Late Maastrichtian to Middle Paleocene, 2) to understand the nature and magnitude of KTB hiatus, and 3) to decipher the tectonic and sedimentary processes involved in the canyon formation and evolution.

\section{Materials and Methods}

Foraminiferal data from 34 wells belonging to major structures located along the canyon was evaluated. Data from Ariyalur outcrops and 10 wells from Tanjore sub basin were also analysed to have a complete KTB picture of the basin behaviour from margin to deeper parts. A total of eleven profiles, eight across, two along and one outside the canyon were studied. However for the purpose of brevity and proportional representation, only six profiles involving 28 well sections are presented here (Fig. 2). Benthic foraminiferal data was utilized to decipher paleo bathymetry across KTB. The KTB depth (MSL) was plotted against each location from west to east which gives an idea of basin floor topography during KTB.

\section{Results}

The Profile 1a is the western most profile connecting wells AT-A in the northeast and $\mathrm{KN}-\mathrm{AB}$ in the southwest across the western limit of the canyon (Fig. $3)$. The KTB is at $2045 \mathrm{~m}$ in AT-A. Cretaceous foraminifera at $2045 \mathrm{~m}$ consist of Globotruncana linneiana, Heterohelix and Rugoglobigerina. This assemblage corresponds to Racemiguembelina fructicosa zone (planktic zones CF-6 and CF-5). The presence of Morozovella velascoensis and Subbotina triloculinoides in sediments above $2045 \mathrm{~m}$ suggests that planktic zone P3 of Paleocene directly overlies Cretaceous. Abathomphalus mayaroensis, Pseudoguembelina hariaensis and Plummerita hantkeninoides zones in the Maastrichtian and 4 zones (P0-P2 Zones) in Paleocene are missing. This suggests a hiatus of $\sim 8.6 \mathrm{Ma}$ across KTB.

In well $\mathrm{KN}-\mathrm{AB}$ the $\mathrm{KTB}$ is at $1930 \mathrm{~m}$ based on first down hole occurrence (FDO) of Globotruncana aegyptiaca and $G$. linneiana which marks Racemiguembelina fructicosa zone. The presence of Morozovella velascoensis and Subbotina triangularis in sediments above $1930 \mathrm{~m}$ suggests that P3 zone of Paleocene overlies Cretaceous. The KTB hiatus is of the order of $\sim 8.6 \mathrm{Ma}$ across KTB.

The occurrence of Pullenia cretacea, Praebulimina carseyae and Lenticulina muensteri in the terminal Cretaceous suggests upper bathyal to outer neritic environment. The benthics such as Allomorphina, Lenticulina and Praebulimina in 


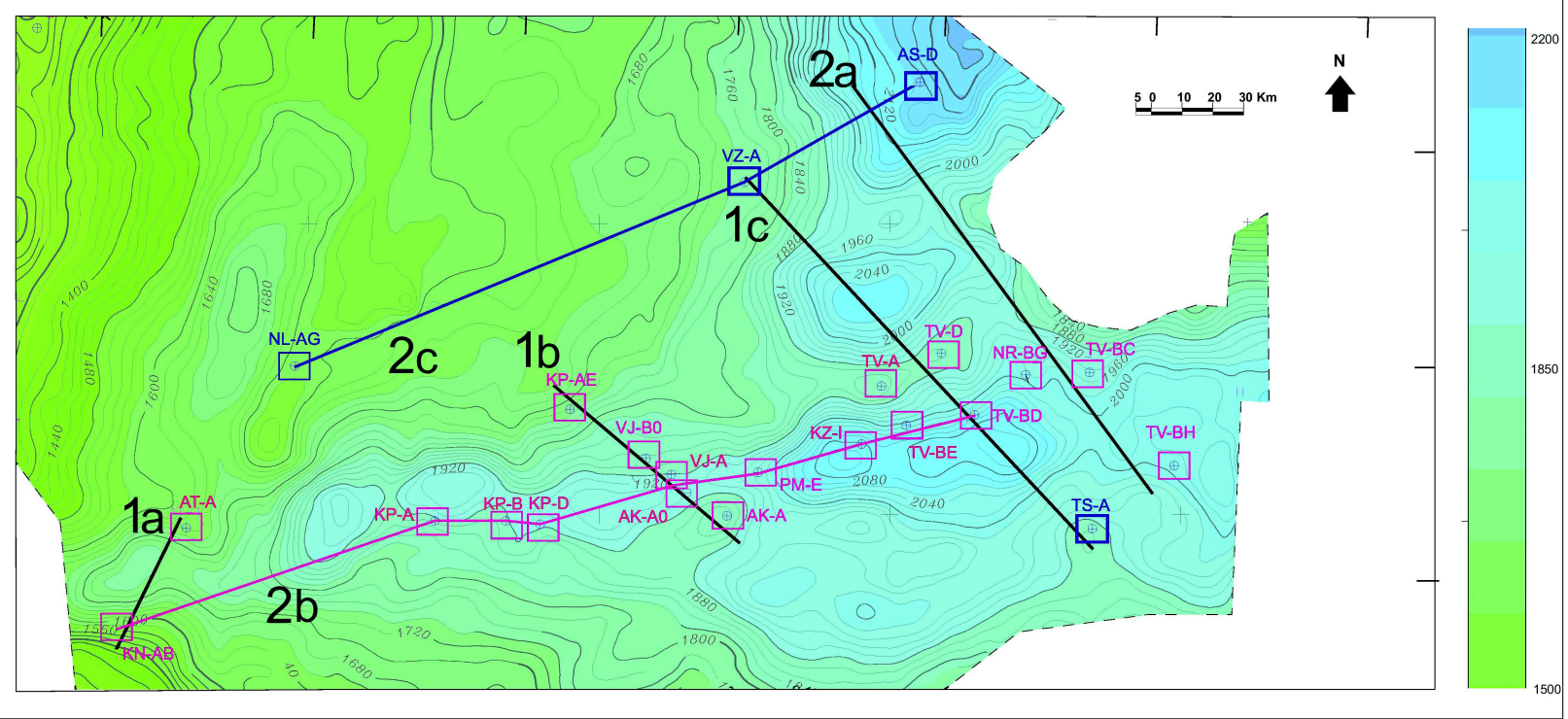

Fig. 2: Time structure map at $\mathrm{K} / \mathrm{T}$ level in Nagapattinam sub-basin. The studied transverse sections, axial section and a parallel peripheral section along with well locations are shown

Paleocene sediments suggest outer neritic environment.

This profile $1 \mathrm{~b}$ runs across the axis of the canyon from northwest to southeast and passes through the wells KP-AE, VJ-B0, VJ-A, AK-A0 and AK-A (Fig. 3 ). In KP-AE, the Cretaceous top is at $2220 \mathrm{~m}$. The foraminifera recorded are Globotruncana arca, $G$. linneiana and Globotruncanita stuarti. This assemblage corresponds to Racemiguembelina fructicosa zone (planktic zones CF-6 and CF-5). The presence of Globoconusa daubjergensis in sediments above $2220 \mathrm{~m}$ suggests that $\mathrm{P} 1$ zone of Paleocene directly overlies Cretaceous.

The absence of latest three planktic zones in Maastrichtian and bottom two zones (P0-P $\alpha$ Zones) in Paleocene suggests a hiatus of $\sim 4.1 \mathrm{Ma}$ across KTB. The occurrence of benthics Kalamopsis grazybowski and Thalmanammina subturbinata in Cretaceous and Paleocene across KTB suggests upper bathyal environment.

In VJ-B0, Cretaceous top is marked at $2435 \mathrm{~m}$ based on FDO of Globotruncana arca and $G$. ventricosa which corresponds to Racemiguembelina fructicosa zone. The presence of Morozovella velascoensis in sediments above $2435 \mathrm{~m}$ suggests that P3 zone of Paleocene directly overlies Cretaceous. The absence of three zones (Abathomphalus mayaroensis, Pseudoguembelina hariaensis, Plummerita hantkeninoides zones) in Maastrichtian and four zones (P0-P2 Zones) in Paleocene indicates a hiatus of $\sim 8.6 \mathrm{Ma}$ across KTB. The occurrence of benthics such as Saccammina in Cretaceous and Saccammina and Thalmanammina subturbinata in Paleocene suggests upper bathyal depositional conditions.

In VJ-A, Cretaceous top is marked at $2450 \mathrm{~m}$ based on FDO of Globotruncana arca, G. linneiana and Globotruncanita stuarti. The concurrent range of this assemblage corresponds to Racemiguembelina fructicosa zone. The presence of Morozovella acuta and Globanomalina pseudomenardii in sediments above $2450 \mathrm{~m}$ suggests $\mathrm{P} 4$ zone of Paleocene directly overlies Cretaceous. The absence of 3 zones (Abathomphalus mayaroensis, Pseudoguembelina hariaensis, Plummerita hantkeninoides zones) in Maastrichtian and 5 zones (P0-P3 Zones) in Paleocene indicates a hiatus of $\sim 9.1 \mathrm{Ma}$ across KTB. The occurrence of Thalmanammina subturbinata and Spiroplectammina navarroana across KTB suggests upper bathyal depositional environment.

In AK-A0 Cretaceous top is at $2550 \mathrm{~m}$ based on FDO of Globotruncana arca and G. linneiana which corresponds to Racemiguembelina fructicosa zone. The presence of Morozovella acuta, M. angulata and $M$. velascoensis in sediments above $2550 \mathrm{~m}$ 


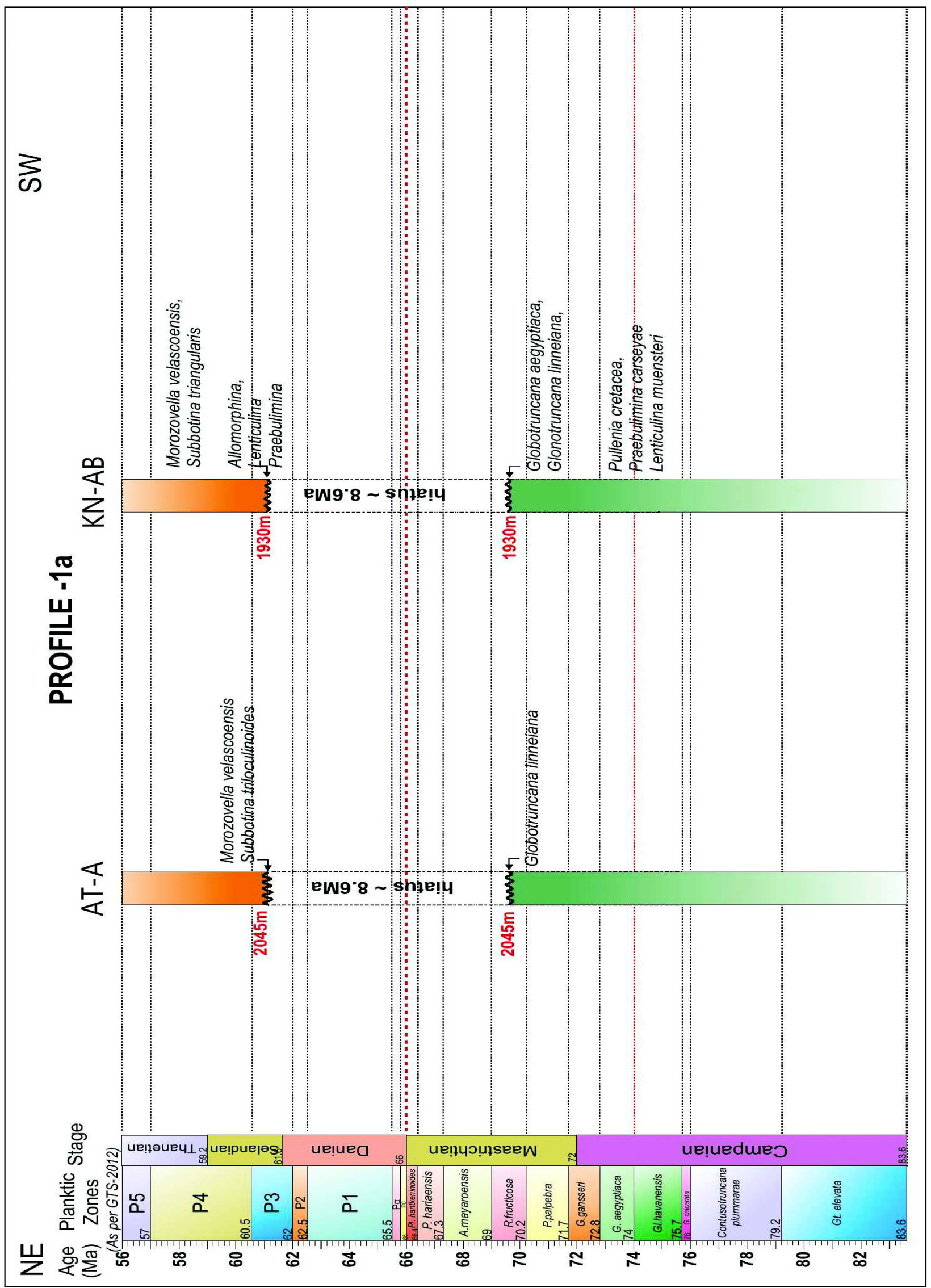




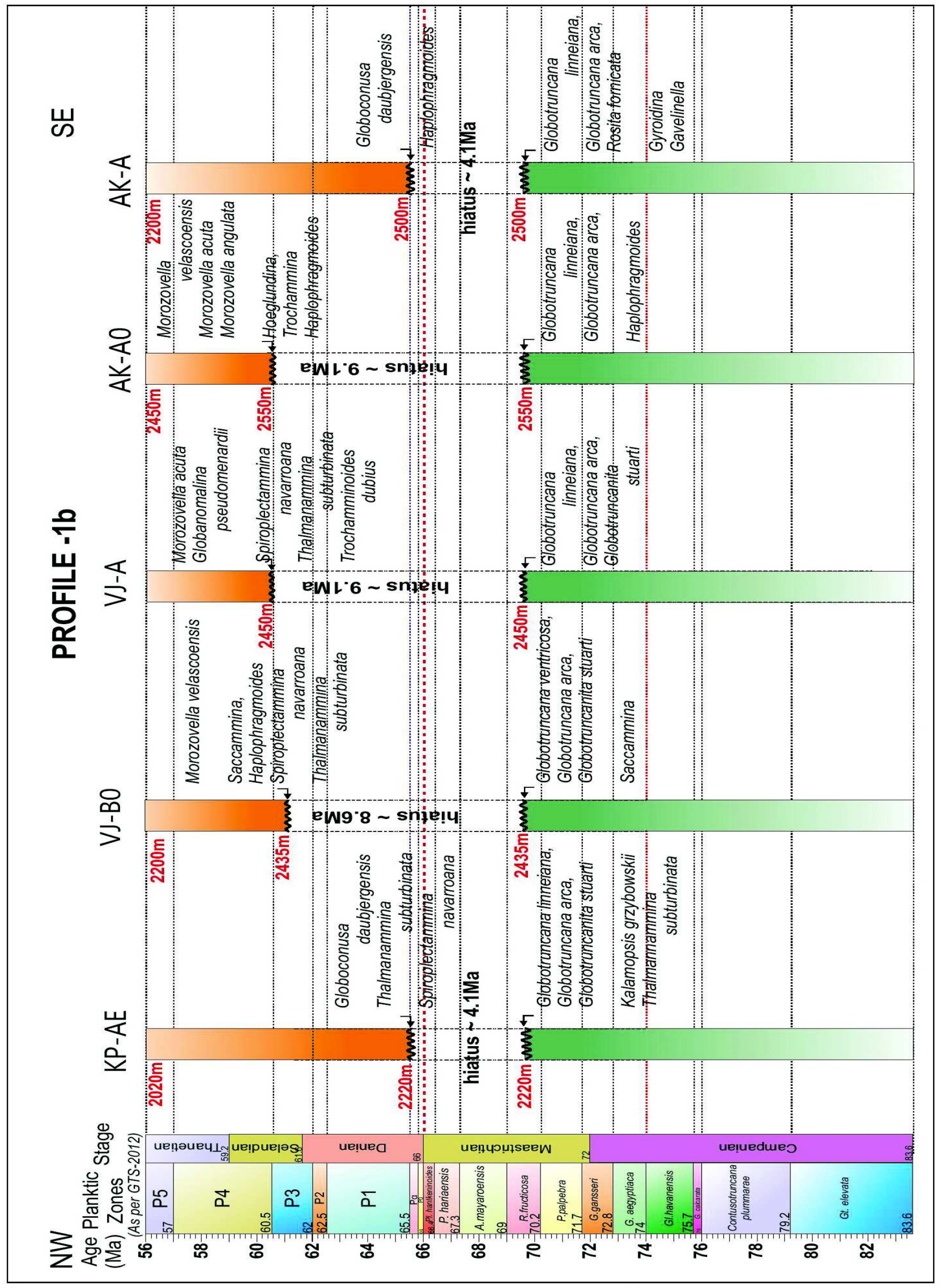




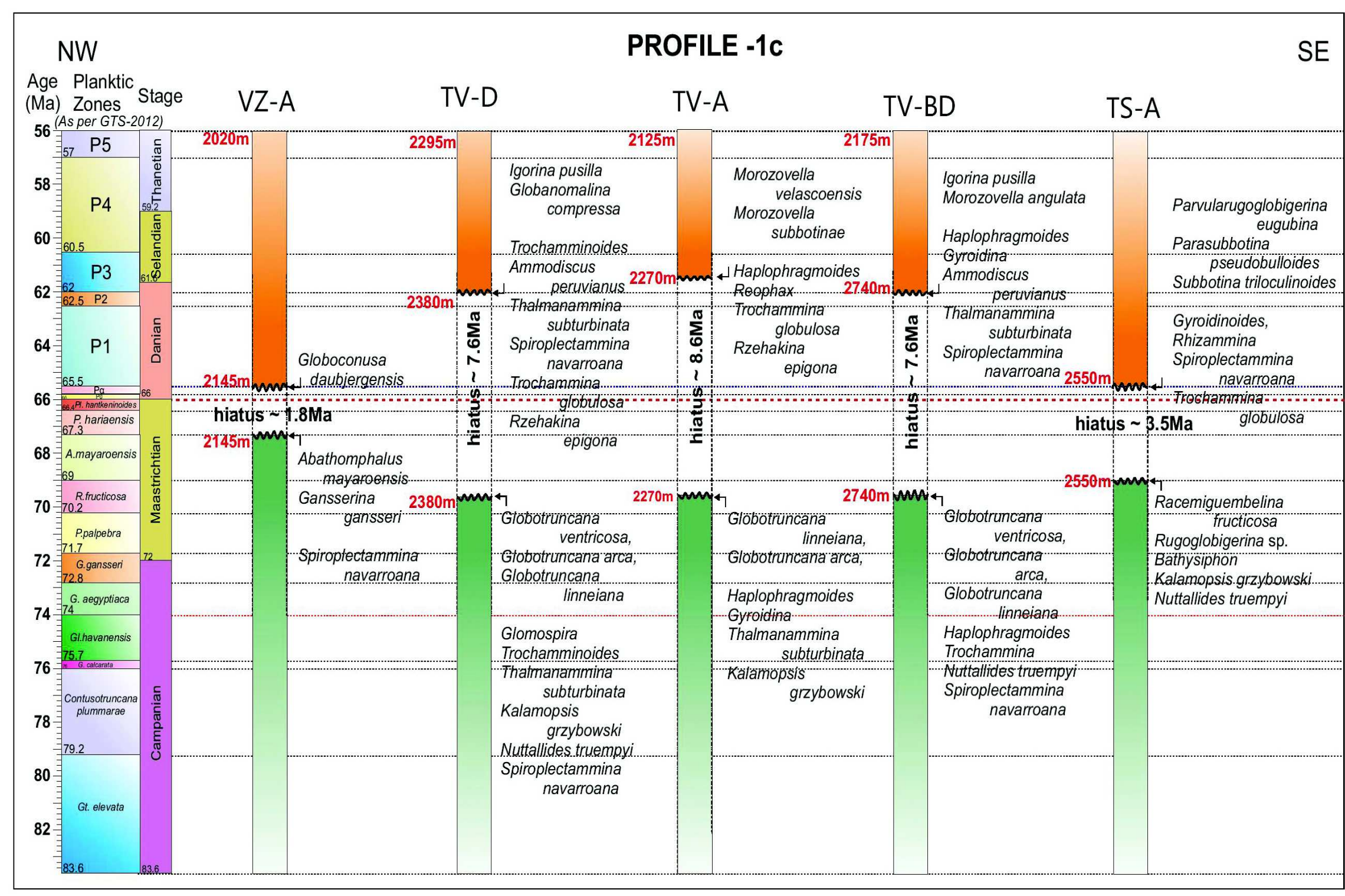

Fig. 3: Profile 1a showing the GTS-2012 and the magnitude of KTB hiatus across the wells AT-A and KN-AB. Profile 1b showing the GTS-2012 and the magnitude of KTB hiatus across the wells KP-AE, VJ-B0, VJ-A, AK-A0 and AK-A. Profile 1c showing the GTS-2012 and the magnitude of KTB hiatus across the wells VZ-A, TV-D, TVA, TV-BD and TS-A 
suggests that $\mathrm{P} 4$ zone of Paleocene directly overlies Cretaceous. The absence of 3 terminal Cretaceous zones (Abathomphalus mayaroensis, Pseudoguembelina hariaensis, Plummerita hantkeninoides zones) in Maastrichtian and 5 zones (P0-P3 Zones) in Paleocene suggests a hiatus of $\sim 9.1 \mathrm{Ma}$ across KTB. The occurrence of deep water arenaceous benthics Haplophragmoides in Cretaceous sediments and Trochammina and Haplophragmoides in Paleocene suggests upper bathyal environment.

In AK-A Cretaceous top is marked at $2500 \mathrm{~m}$ based on FDO of Globotruncana arca, G. linneiana and Rosita fornicata which corresponds to Racemiguembelina fructicosa zone. The presence of Globoconusa daubjergensis in sediments above $2500 \mathrm{~m}$ suggests that $\mathrm{P} 1$ zone of Paleocene directly overlies Cretaceous. The absence of 3 zones (Abathomphalus mayaroensis, Pseudoguembelina hariaensis, Plummerita hantkeninoides zones) in Maastrichtian and 2 zones (P0-P $\alpha$ Zones) in Paleocene marks a hiatus of $\sim 4.1 \mathrm{Ma}$ across KTB. In this profile the wells KP-AE and AK-A are located on the flank of the canyon whereas VJ-B0, VJ-A and $\mathrm{AK}-\mathrm{A} 0$ are on the main axis of the canyon. The hiatus in the flank wells is $\sim 4-5 \mathrm{Ma}$. In the axial portion the hiatus is of the order of $\sim 7-9 \mathrm{Ma}$. The paleobathymetry during Cretaceous and Paleocene is inferred to be upper bathyal based on deep water arenaceous benthics.

The profileic runs from northwest to southeast across the canyon and passes through the wells VZA, TV-D, TV-A, TV-BD and TS-A (Fig. 3). In VZA, Cretaceous top is at $2145 \mathrm{~m}$ based on FDO of Abathomphalus mayaroensis which belongs to Abathomphalus mayaroensis zone. The presence of Globoconusa daubjergensis in sediments above $2145 \mathrm{~m}$ suggests that P1 zone of Paleocene directly overlies Cretaceous. The absence of Pseudoguembelina hariaensis and Plummerita hantkeninoides zone in Maastrichtian and $\mathrm{P} 0-\mathrm{P} \alpha$ Zones in Paleocene suggests a hiatus of $\sim 1.8 \mathrm{Ma}$ across KTB. The presence of arenaceous benthic taxon Spiroplectammina navarroana in the terminal Cretaceous sediments indicates upper bathyal depositional conditions.

In TV-D, Cretaceous top is at $2380 \mathrm{~m}$ based on FDO of Globotruncana linneiana, G. arca and $G$. ventricosa whose concurrent range corresponds to
Racemiguembelina fructicosa zone. The presence of Globanomalina compressa and Igorina pusilla in sediments above $2380 \mathrm{~m}$ suggests that P3 zone of Paleocene directly overlies Cretaceous. The absence of 3 zones (Abathomphalus mayaroensis, Pseudoguembelina hariaensis and Plummerita hantkeninoides zones) in Maastrichtian and 4 zones (P0-P2 Zones) in Paleocene suggests a hiatus of $~ 7.6$ Ma across KTB. The occurrence of Nuttallides truempyi, Thalmanammina subturbinata in Cretaceous and Thalmanammina subturbinata, Spiroplectammina navarroana in Paleocene suggest upper to middle bathyal depositional environment.

In TV-A, Cretaceous top is at $2270 \mathrm{~m}$ based on FDO of Globotruncana linneiana, G. arca corresponding to Racemiguembelina fructicosa zone. The presence of Morozovella velascoensis in sediments above $2270 \mathrm{~m}$ suggests that P3 zone of Paleocene directly overlies Cretaceous. The absence of 3 zones (Abathomphalus mayaroensis Pseudoguembelina hariaensis -Plummerita hantkeninoides zones) in Maastrichtian and 4 zones (P0-P2 Zones) in Paleocene indicates a hiatus of $8.6 \mathrm{Ma}$ across KTB. The occurrence of Thalmanammina subturbinata, Kalamopsis grazybowski and Haplophragmoides in Cretaceous and Haplophragmoides, Reophax duplex in Paleocene suggests upper to middle bathyal environment.

In TV-BD, Cretaceous top is at $2740 \mathrm{~m}$ based on FDO of Globotruncana linneiana, G.arca and G.ventricosa corresponding to Racemiguembelina fructicosa zone. The presence of Morozovella angulata and Igorina pusilla in sediments above 2740m suggests that $\mathrm{P} 3$ zone of Paleocene directly overlies Cretaceous. The absence of 3 zones (Abathomphalus mayaroensis - Pseudoguembelina hariaensis - Plummerita hantkeninoides zones) in Maastrichtian and 4 zones (P0-P2 Zones) in Paleocene marks a hiatus of $\sim 7.6 \mathrm{Ma}$ across KTB. The occurrence of Nuttalides truempyi, Spiroplectammina navarroana in Cretaceous and Thalmanammina subturbinata, Spiroplectammina navarroana in Paleocene suggest upper to middle bathyal environment.

In TS-A, Cretaceous top is at $2550 \mathrm{~m}$ based on FDO of Racemiguembelina fructicosa belonging to Racemiguembelina fructicosa zone. The presence 
of Parvularugoglobigerina eugubina and Parasubbotina pseudobulloides in sediments above $2550 \mathrm{~m}$ suggests that $\mathrm{P} 1$ zone of Paleocene directly overlies Cretaceous. The absence of 3 zones (Abathomphalus mayaroensis, Pseudoguembelina hariaensis and Plummerita hantkeninoides zones) in Maastrichtian and 2 zones (P0-P $\alpha$ Zones) in Paleocene marks a hiatus of $\sim 3.5 \mathrm{Ma}$ across KTB. The occurrence of Nuttallides truempyi in Cretaceous and Spiroplectammina navarroana in Paleocene suggest upper to middle bathyal environment across KTB. In this profile the wells VZ$A$ and TS-A are located at the periphery and flank of the canyon respectively while TV-D, TV-A and TV$\mathrm{BD}$ are in the axial region.

The profile 2 a runs almost north to south across the canyon through the wells AS-D, NR-BG, TV-BC and TV-BH (Fig. 4). In AS-D, Cretaceous top is at $2730 \mathrm{~m}$ based on FDO of Rugoglobigerina rugosa, Globotruncanella petaloidea which corresponds to Abathomphalus mayaroensis zone. The presence of Subbotina trivialis in sediments above $2730 \mathrm{~m}$ suggests that $\mathrm{P} 1$ zone of Paleocene directly overlies Cretaceous. The absence of Pseudoguembelina hariaensis and Plummerita hantkeninoides zone in the latest Maastrichtian and $\mathrm{P} 0$ and $\mathrm{P} \alpha$ Zone in Paleocene indicates a hiatus of $\sim 1.8 \mathrm{Ma}$ across KTB. The occurrence of Nuttallides truempyi, Spiroplectammina navarroana in Cretaceous and Thalmanammina subturbinata, Dorothia oxycona in Paleocene suggests upper to middle bathyal environment.

In NR-BG, Cretaceous top is at $2620 \mathrm{~m}$ based on FDO of Globotruncana linneiana and $G$. bulloides. This assemblage corresponds to Racemiguembelina fructicosa zone. The presence of Morozovella velascoensis in sediments above $2620 \mathrm{~m}$ suggests that P3 zone of Paleocene directly overlies Cretaceous. The absence of 3 zones (Abathomphalus mayaroensis, Pseudoguembelina hariaensis and Plummerita hantkeninoides zones) in the latest Maastrichtian and 4 zones (P0-P2 Zones) in Paleocene suggests a hiatus of $\sim 8.6 \mathrm{Ma}$ across KTB. Occurrence of Trochammina and Haplophragmoides in the terminal Cretaceous and Ammodiscus cretaceous in Paleocene sediments suggests upper to middle bathyal depositional conditions.
In TV-BC, Cretaceous top is marked at $2505 \mathrm{~m}$ based on FDO of Globotruncanita stuarti which corresponds to Racemiguembelina fructicosa zone. The presence of Morozovella velascoensis in sediments above $2505 \mathrm{~m}$ suggests that P3 zone of Paleocene directly overlies Cretaceous. The absence of 3 zones (Abathomphalus mayaroensis, Pseudoguembelina hariaensis and Plummerita hantkeninoides zones) in Maastrichtian and 4 zones (P0-P2 Zones) in Paleocene marks a hiatus of $~ 8.6$ Ma across KTB. The occurrence of Nuttallides truempyi, Spiroplectammina navarroana in Cretaceous and Thalmanammina subturbinata, Spiroplectammina navarroana in Paleocene suggests middle to upper bathyal environment.

In TV-BH, Cretaceous top is at $2500 \mathrm{~m}$ based on FDO of Globotruncana linneiana and G.ventricosa corresponding to Racemiguembelina fructicosa zone. The presence of Subbotina trivialis and Parasubbotina pseudobulloides in sediments above $2500 \mathrm{~m}$ suggests that P1 zone of Paleocene directly overlies Cretaceous. The absence of 3 zones (Abathomphalus mayaroensis, Pseudoguembelina hariaensis and Plummerita hantkeninoides zones) in Maastrichtian and 2 zones ( $\mathrm{P} 0-\mathrm{P} \alpha$ Zones) in Paleocene marks a hiatus of $\sim 4.1$ Ma across KTB. The occurrence of Spiroplectammina navarroana in Cretaceous and Ammodiscus peruvianus, Spiroplectammina navarroana in Paleocene suggests upper bathyal environment. In this profile, the well AS-D is located at the periphery of the canyon whereas NR-BG and TV-BC are in the axial region. The hiatus in the peripheral portion of the canyon is $\sim 1.8 \mathrm{Ma}$ whereas in the axial portion it is of the order of $\sim 7-9 \mathrm{Ma}$. The well TV-BH, which lies on the flank of canyon shows an unconformity of $\sim 4 \mathrm{Ma}$.

Profile $2 b$ is plotted along the axis of the canyon. From west to east, the profile passes through the wells KN-AB, KP-A, KP-B, KP-D, VJ-A, AK-A0, PME, KZ-I and TV-BD (Fig. 4). Among these nine wells under consideration, Cretaceous top level is common to all with the occurrence of Globotruncana aegyptiaca, G. arca, G. linneiana, G. ventricosa, and G. stuarti. The concurrent range of these species corresponds to Racemiguembelina fructicosa zone. The benthic assemblage includes Lenticulina, Hyperammina and Haplophragmoides in wells west of AK-A0 while the sections from PM-E, KZ-I and 


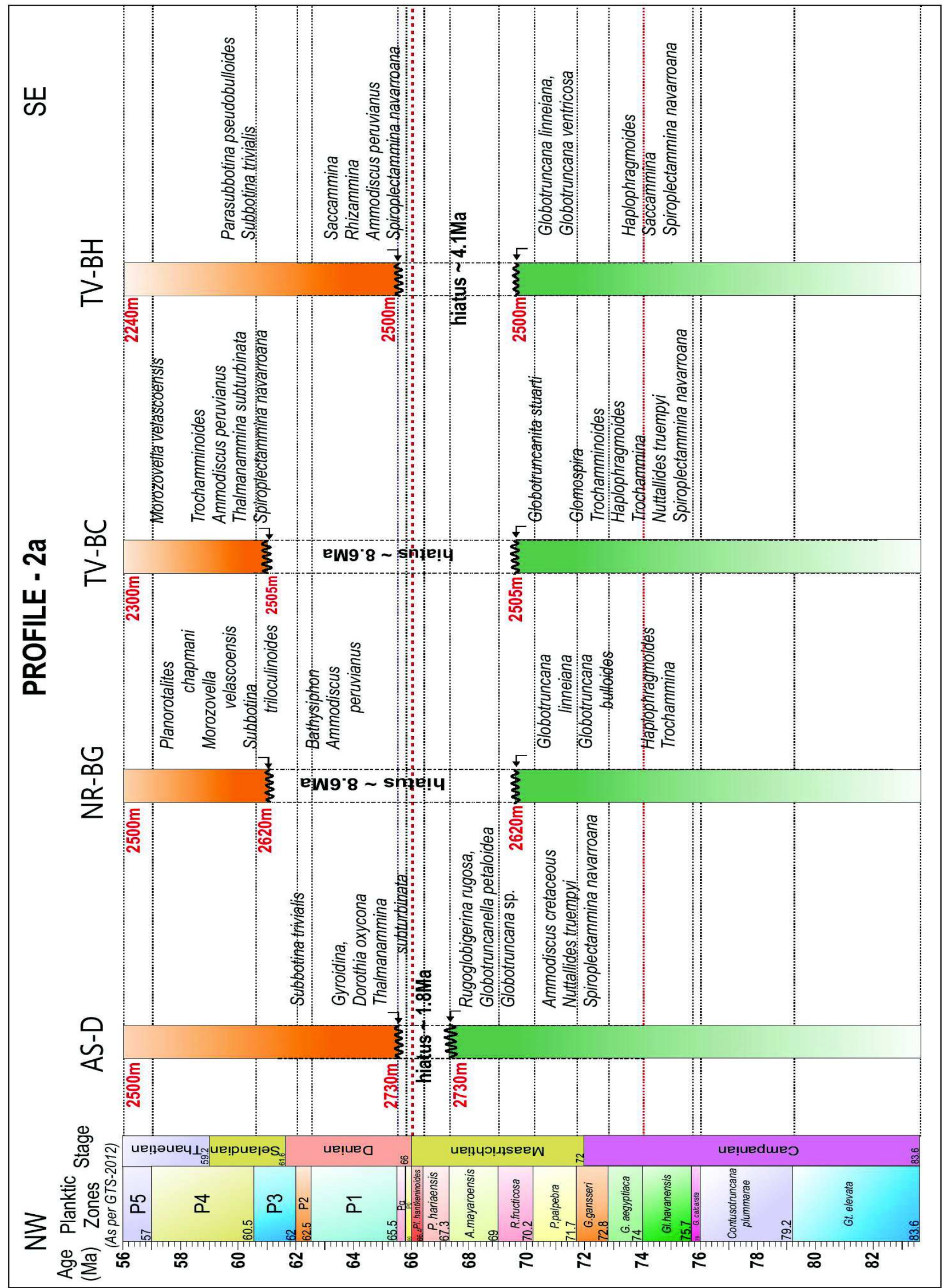




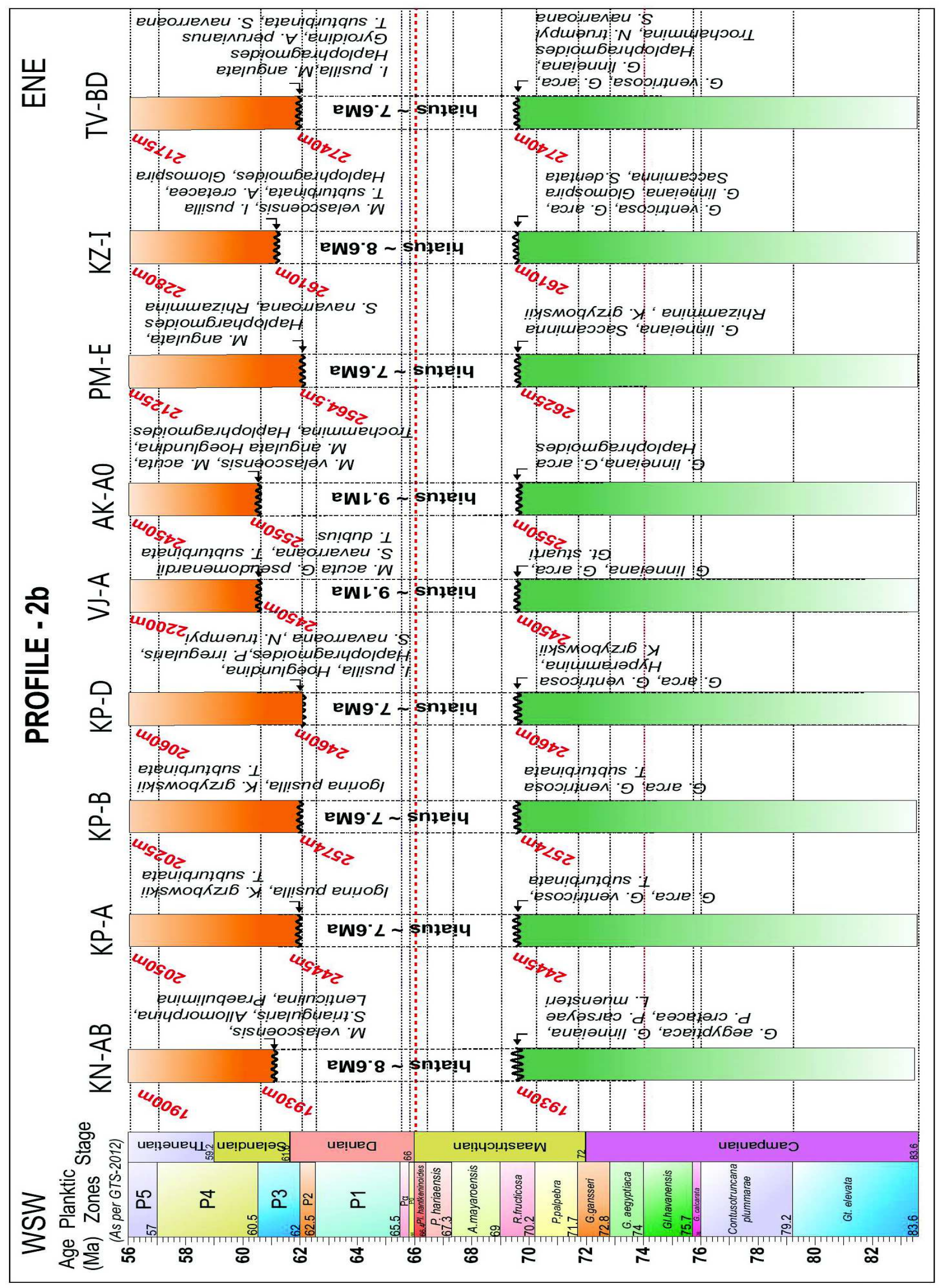




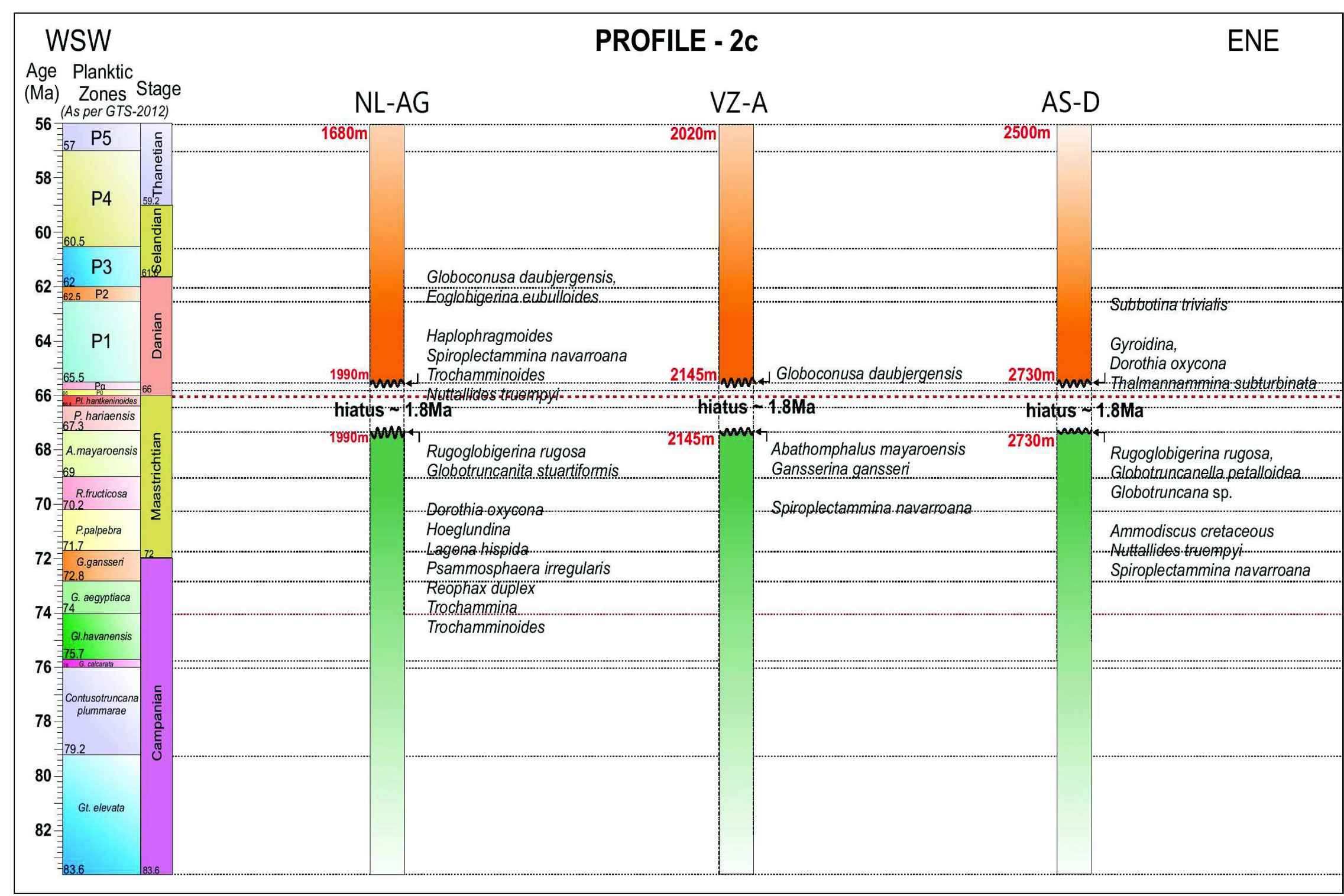

Fig. 4: Profile 2a showing the GTS-2012 and the magnitude of KTB hiatus across the wells AS-D, NR-BG, TV-BC and TV-BH. Profile 2b showing the GTS-2012 and the magnitude of KTB hiatus across the wells KN-AB, KP-A, KP-B, KP-D, VJ-A, AK-A0, PM-E, KZ-I and TV-BD. Profile 2c showing the GTS-2012 and the magnitude of KTB hiatus across the wells NL-AG, VZ-A and AS-D 
TV-BD areas contain Nuttallides truempyi which is middle slope benthic foraminifera. This benthic assemblage indicates an outer shelf environment near $\mathrm{KN}-\mathrm{AB}$ section and becoming deeper to middle slope conditions in PM-E, KZ-I and TV-BD areas.

In the Paleocene section, the well $\mathrm{KN}-\mathrm{AB}$ has yielded foraminifera of planktic zone P3 immediately above KTB at $1930 \mathrm{~m}$. They consist of Morozovella velascoensis and Subbotina triangularis suggesting the presence of planktic zone P3. The absence of 3 zones (Abathomphalus mayaroensis, Pseudoguembelina hariaensis and Plummerita hantkeninoides zones) in Maastrichtian and 4 zones (P0-P2 Zones) in Paleocene marks a hiatus of $\sim 8.6 \mathrm{Ma}$ across KTB. Similar assemblage and hiatus is recorded in well KZA. In sections KP-A, KP-B, KP-D, PM-E and TV$\mathrm{BD}$ the $\mathrm{P} 3$ assemblage consisting of Igorina pusilla, Morozovella angulata are recorded. The absence of 3 zones (Abathomphalus mayaroensis, Pseudoguembelina hariaensis, Plummerita hantkeninoides zones) in Maastrichtian and 4 zones (P0-P2 Zones) in Paleocene marks a hiatus of $~ 7.6$ $\mathrm{Ma}$ across KTB. The variation in hiatus is mainly due to differential erosion and non-depositional phase post KTB. The canyon was active a bit longer in VJ-A and $\mathrm{AK}-\mathrm{A} 0$ areas.

The benthic foraminifera in Paleocene sediments include Hoeglundina, Haplophragmoides, Nuttallides truempyi, Spiroplectammina navarroana, Glomospira and Ammodiscus peruvianus. All these are outer shelf to middle bathyal benthics indicating the prevalence of deep water depositional conditions post KTB.

The profile $2 \mathrm{c}$ is plotted parallel but away from the axis of the canyon. From west to east, the profile passes through the wells NL-AG, VZ-A and AS-D (Fig. 4). In NL-AG, Cretaceous top is at $1990 \mathrm{~m}$ based on FDO of Rugoglobigerina rugosa and Globotruncanita stuartiformis which corresponds to Abathomphalus mayaroensis zone within Late Maastrichtian. The presence of Globoconusa daubjergensis and Eoglobigerina eobulloides in sediments above $1990 \mathrm{~m}$ suggests that P1 zone of Paleocene overlies Cretaceous. The absence of Pseudoguembelina hariaensis and Plummerita hantkeninoides in Maastrichtian and $\mathrm{P} 0, \mathrm{P} \alpha$ Zone in Paleocene indicates a hiatus of $\sim 1.8 \mathrm{Ma}$ across
KTB. The occurrence of Dorothia oxycona and Reophax duplex in Cretaceous and Nuttalides truempyi in Paleocene suggests middle to upper bathyal paleobathymetry across KTB.

In VZ-A the Cretaceous top is marked at $2145 \mathrm{~m}$ based on FDO of Abathomphalus mayaroensis which also marks the Abathomphalus mayaroensis zone. The presence of Globoconusa daubjergensis in sediments above $2145 \mathrm{~m}$ suggests that P1 zone of Paleocene directly overlies Cretaceous. The absence of Pseudoguembelina hariaensis and Plummerita hantkeninoides zone in Maastrichtian and $\mathrm{P} 0-\mathrm{P} \alpha$ Zone in Paleocene marks a hiatus of $\sim 1.8 \mathrm{Ma}$ across KTB. Bathyal benthics are found across KTB.

In AS-D, Cretaceous top is at $2730 \mathrm{~m}$ based on FDO of Rugoglobigerina rugosa, Globotruncanella petaloidea which corresponds to Abathomphalus mayaroensis zone. The presence of Subbotina trivialis in sediments above $2730 \mathrm{~m}$ suggests that P1 zone of Paleocene directly overlies Cretaceous. The absence of Pseudoguembelina hariaensis and Plummerita hantkeninoides zone in Maastrichtian and $\mathrm{P} 0$ and $\mathrm{P} \alpha$ Zone in Paleocene marks a hiatus of $\sim 1.8 \mathrm{Ma}$ across KTB.

The occurrence of Nuttallides truempyi, Spiroplectammina navarroana in Cretaceous and Thalmanammina subturbinata, Dorothia oxycona in Paleocene suggest upper bathyal environment. In this profile all wells are lying on the periphery of the canyon and the KTB hiatus is of the order of $\sim 1.8$ Ma. Possibly, this is the near complete KTB section found in Cauvery Basin.

\section{Discussion}

A total of four transverse sections running perpendicular to the canyon, one along the main axis of the canyon and one parallel section running along the periphery of the canyon were considered for the analysis of hiatus and paleobathymetry across KTB. In the first N-S transverse section consisting wells AT-A and $\mathrm{KN}-\mathrm{AB}$, the magnitude of hiatus is $8.6 \mathrm{Ma}$. In the transverse section covering wells KP-AE, VJB0, VJ-A, AK-A0, AK-A, the wells VJ-B0, VJ-A and $\mathrm{AK}-\mathrm{A} 0$ are located on the axis of the canyon while KP-AE and AK-A are located slightly away from the axis but along the flank of the canyon. The magnitude of hiatus is $\sim 8-9$ Ma in the axial wells and 
4.1 Ma in the flank wells. The third transverse profile runs along the wells VZ-A, TV-D, A, BD and TS A. The KTB hiatus is $1.8 \mathrm{Ma}$ in VZ-A, while it is 3.5 Ma in TS-A. Both these wells are located on the north and south periphery of the canyon respectively. The hiatus is $\sim 7-9 \mathrm{Ma}$ in wells TV-D, TV-A, TV-BD indicating their location in the main canyon area. The fourth transverse profile runs along the wells AS-D, NR-BG, TV-BC and TV-BH.The KTB hiatus in AS$\mathrm{D}$ is $1.8 \mathrm{Ma}$ while it is $\sim 8.6 \mathrm{Ma}$ in NR-BG and TVBC. In TV-BH the magnitude of hiatus is $\sim 4.1 \mathrm{Ma}$. This data suggests that the well AS-D is located on the periphery while TV-BH is located on the inner flank of the canyon and the wells NR-BG and TV$\mathrm{BC}$ are located in the canyon. The fifth profile consists of wells KN-AB, KP-A, KP-B, KP-D, VJ-A, AKA0, PM-E, KZ-I and TV-BD. This profile runs along the axis of the canyon. The magnitude of hiatus is $\sim 7-9$ Ma across KTB. The sixth profile runs parallel to the axis but along the periphery of the canyon. The profile consists of wells NL-AG, VZ -A and AS-D. The magnitude of hiatus is $1.8 \mathrm{Ma}$.

A deep water benthic marker species Nuttallides truempyi whose upper habitable limit of $>500 \mathrm{~m}$ (Morkhoven et al.1983; Reddy and Yadagiri, 2001; Reddy et al. 2013) is recorded in most of the wells east of Kuthanallur area across KTB. However, in the well sections west of Kuthanallur, benthics indicating neritic conditions have been found. The paleobathymetric variation along west to east direction evidently suggests that there was a relative sea level fall by more than $100 \mathrm{~m}$. The foraminiferal data from Tanjore subbasin wells VT-A, VT-C, KG-A, KG-B, KNP-A, ON-A, NV-B, VD-E, RM-A, GDV-A indicates that the area west of ON-A and KG-A was exposed and thus continental sediments are resting directly over marine Cretaceous sediments. The presence of broken inoceramus shells in VD-E, NV$\mathrm{B}$, and NV-A indicates reworking of sediments in very shallow marine or subareal exposed conditions at KTB. The shelf slope system is not evident and possibly was represented by a narrow shelf with steep gradient. The shelf edge at KTB lies possibly between Nidamangalam (NM) and Nannilam (NL) areas running parallel/along the eastern margin of Pattukottai and Kumbakonam highs.

The analysis of the hiatus and paleobathymetry reveals that the hiatus was erosional in the terminal
Cretaceous creating a diachronous surface and nondepositional to erosional in Early Paleocene. The minimum hiatus of $1.8 \mathrm{Ma}$ represents the nondepositional unconformity. This suggests that the entire area received the sediments till at least $0.5 \mathrm{Ma}$ prior to KTB. Probably it was at this point of time, due to doming effect of the Indian subcontinent (Keller et $a l ., 2016)$ the basin got uplifted and tilted eastward. This phenomenon possibly disrupted the sedimentation process. The shallower shelf area of Tanjore subbasin got exposed upto Kannanthangudi area. Erosional processes involving shelf edge collapse, slumping, sliding, debris flow dominated the upper to middle slope area creating the canyon feature. Maximum erosion took place along the axis of the canyon resulting in attrition of middle to late Maastrichtian sediments at all the locations.

There is a clear correlation of timing of KTB canyon formation in Cauvery Basin and the Deccan volcanism event linked to the rise of Reunion hot mantle plume. The plume elevated west central and peninsular India by over $1 \mathrm{~km}$ (White and Mackenzie, 1989, Courtillot, 1990) before causing Deccan flood basalts. These basalts are preserved across KTB in Krishna Godavari Basin as trap flows which protected the intertrappean sediments from erosion (Jaiprakash et al., 1993; Keller et al., 2011,2016). These traps did not reach the Cauvery basin because of absence of drainage systems connecting to the main Deccan province. Consequently, the terminal Cretaceous sediments were subjected to erosional processes. The total duration of main Deccan volcanism involving phase -2 and 3 covers from $66.2 \mathrm{Ma}$ to $65 \mathrm{Ma}$ (considering KTB at $66 \mathrm{Ma}$ as per GTS-2012) across KTB. This is the period of erosion in the terminal Cretaceous and non deposion/erosion during Early Paleocene. This suggests that the rise of Reunion hot mantle plume (Courtillot, 1990) over which Indian plate was sliding northwards during KTB had a role in the basinal uplift and tilting. This has triggered a chain of sedimentary processes involving shelf edge collapse, slumping, sliding and debris flows resulting in the genesis of canyon and other erosional features in the Cauvery Basin.

Fig. 5 is a composite diagram depicting the chain of geological events that occurred across KTB. These events such as relative sea level fall by $100 \mathrm{~m}$ in the basin, sub aerial exposure of Ariyalur outcrops, 


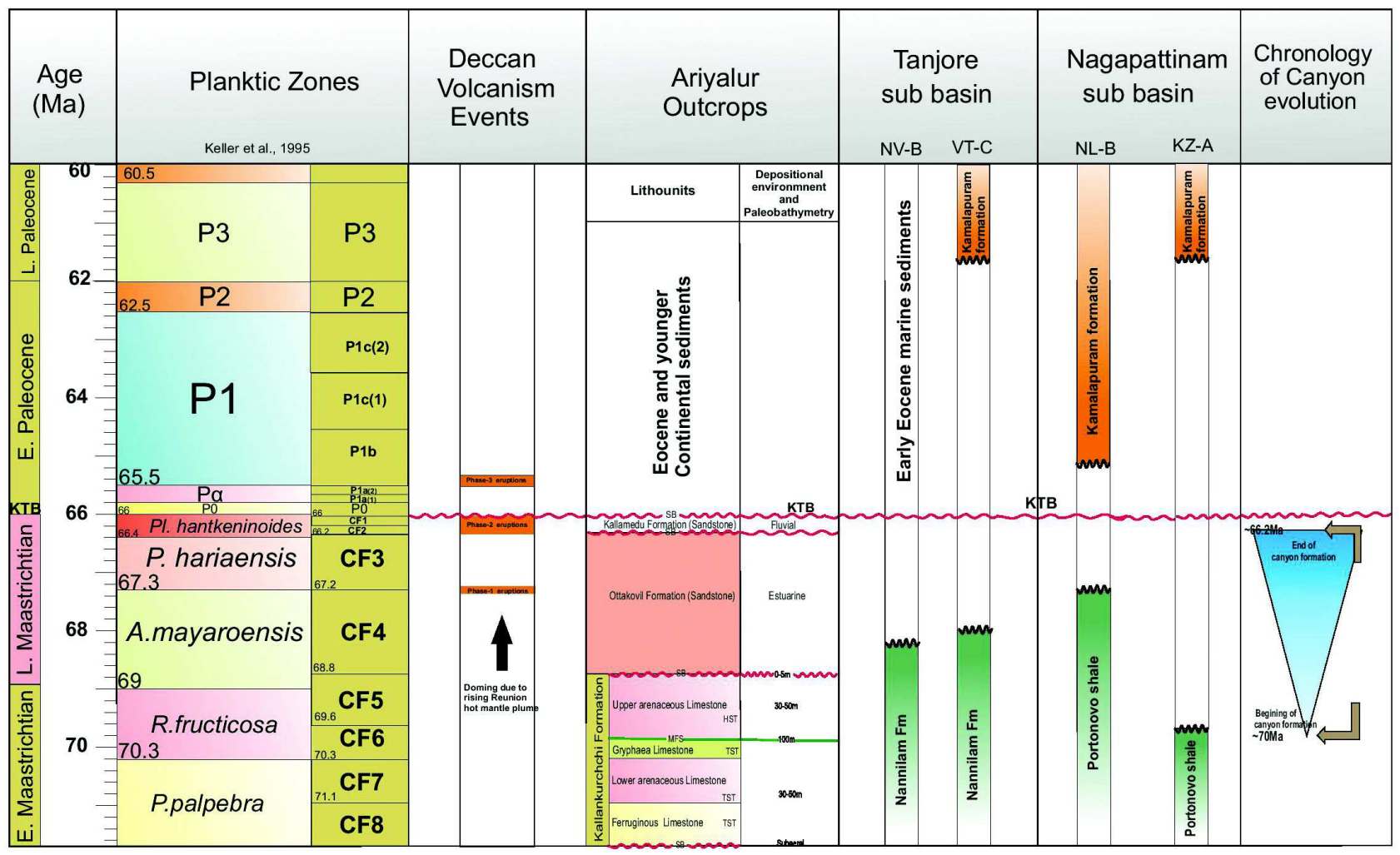

Fig. 5: Composite diagram depicting genetic linkage of Deccan volcanism to KTB events in Cauvery Basin from outcrops to Tanjore sub-basin to Nagapattinam sub-basin. The diagram also gives the biochrono and tectono stratigraphic framework of the origin and evolution of the KTB canyon

followed by exposure of areas west of Neduvasal and Orathanadu and triggering of canyon formation appears to be progressively ordered in time. This is indicative of genetic linkage to a larger tectonic event during KTB. The only major tectonic event of catastrophic scale that has been recorded in the entire Indian subcontinent is the Deccan volcanism linked to rise of Reunion hot mantle plume (Courtillot, 1990; White and McKenzie, 1989; Keller et al., 2011, 2016)

In Ariyalur outcrops, the Kallankurichhi Formation (Fig. 5) of EarlyMaastrichtian age is exposed. This formation is divided into four members: the ferruginous limestone at the bottom, lower arenaceous limestone, Gryphea limestone and upper arenaceous limestone at the top. Maximum Flooding surface (MFS) has been recorded in the Gryphea limestone (Nagendra et al, 2002, 2011). The MFS falls within the planktic zone CF6 (70.3-69.6Ma). This was the period when the entire Cauvery Basin was under open marine conditions (Fig. 6). Around this time, the rise of Reunion hot mantle plume was emerging in the Deccan province initiating the doming effect of west, central and peninsular India. This doming probably resulted in basinal uplift and eastward tilt of the Cauvery Basin. As a response, canyon formation/erosional activities got initiated in many sub basins of Cauvery Basin including Nagapattinam sub basin. However, soon after this event, the topmost upper arenaceous unit was deposited as a response to falling sea level. The sea level fall began at the boundary of planktic zones CF6-CF5 (69.6Ma) as recorded in the outcrops (Nagendra et al., 2002, 2011). The Kallankurichhi Formation got exposed at the end of planktic zone CF5 (68.8 Ma) and remain exposed to this day. The fall in sea level was of the order of $100 \mathrm{~m}$. Subsequently, areas west of Orathanadu got exposed in lower part of planktic zone CF4 ( 68Ma). The area east of Orathanadu and upto Kuthanallur was in steeply dipping shelfal regime. The areas Nannilam, Kamalapuram, Tiruvarur, Kizhavalur, and Pallivaramangalam remained under deep marine (upper to middle slope) with reduced sea level. The KTB shelf edge lies between Nidamangalam - 


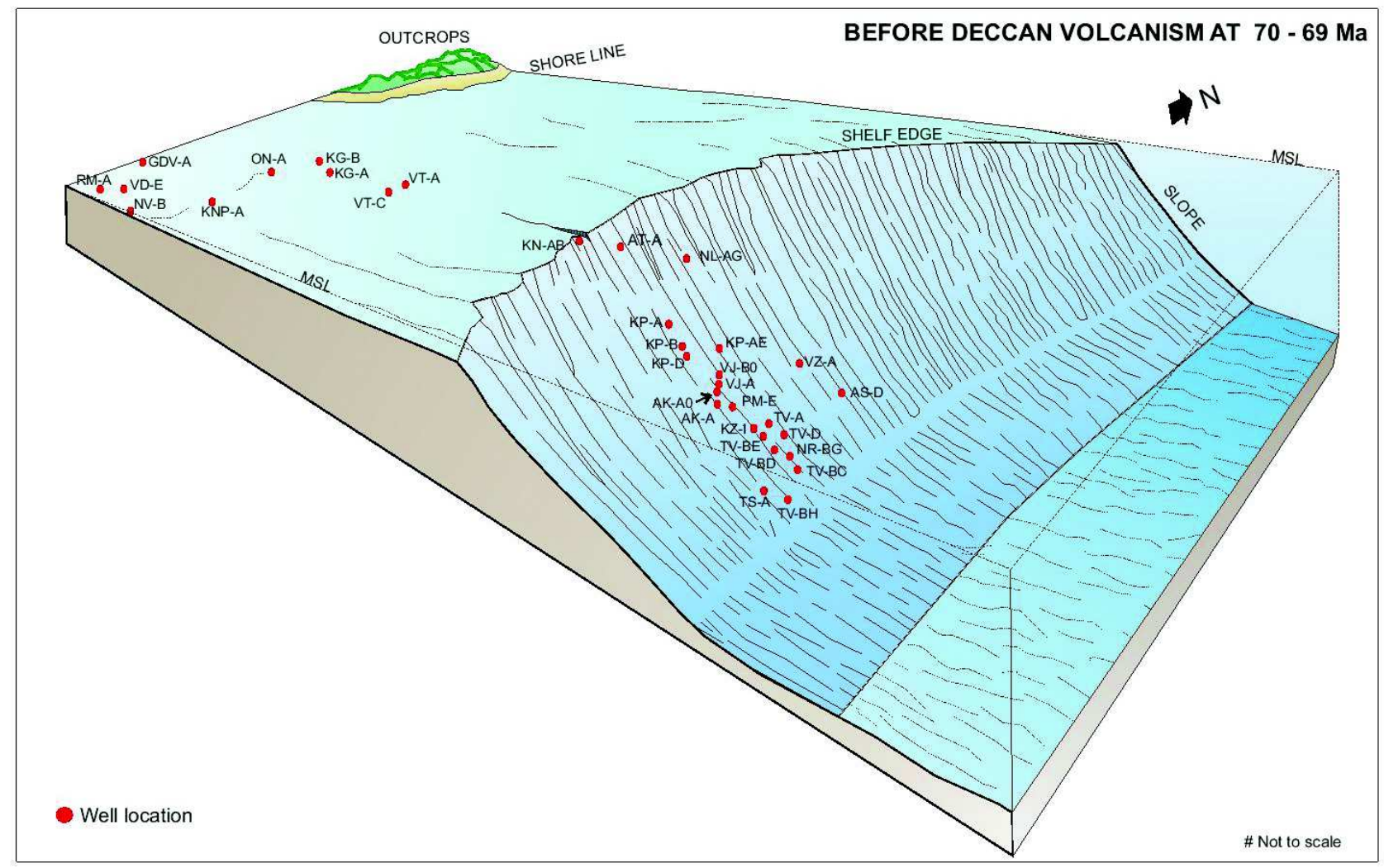

Fig. 6: 3-dimensional block diagram of Nagapattinam sub-basin w.r.t outcrops and Tanjore sub-basin at 69-70 Ma. Also the figure gives the basin profile during that period along with well locations

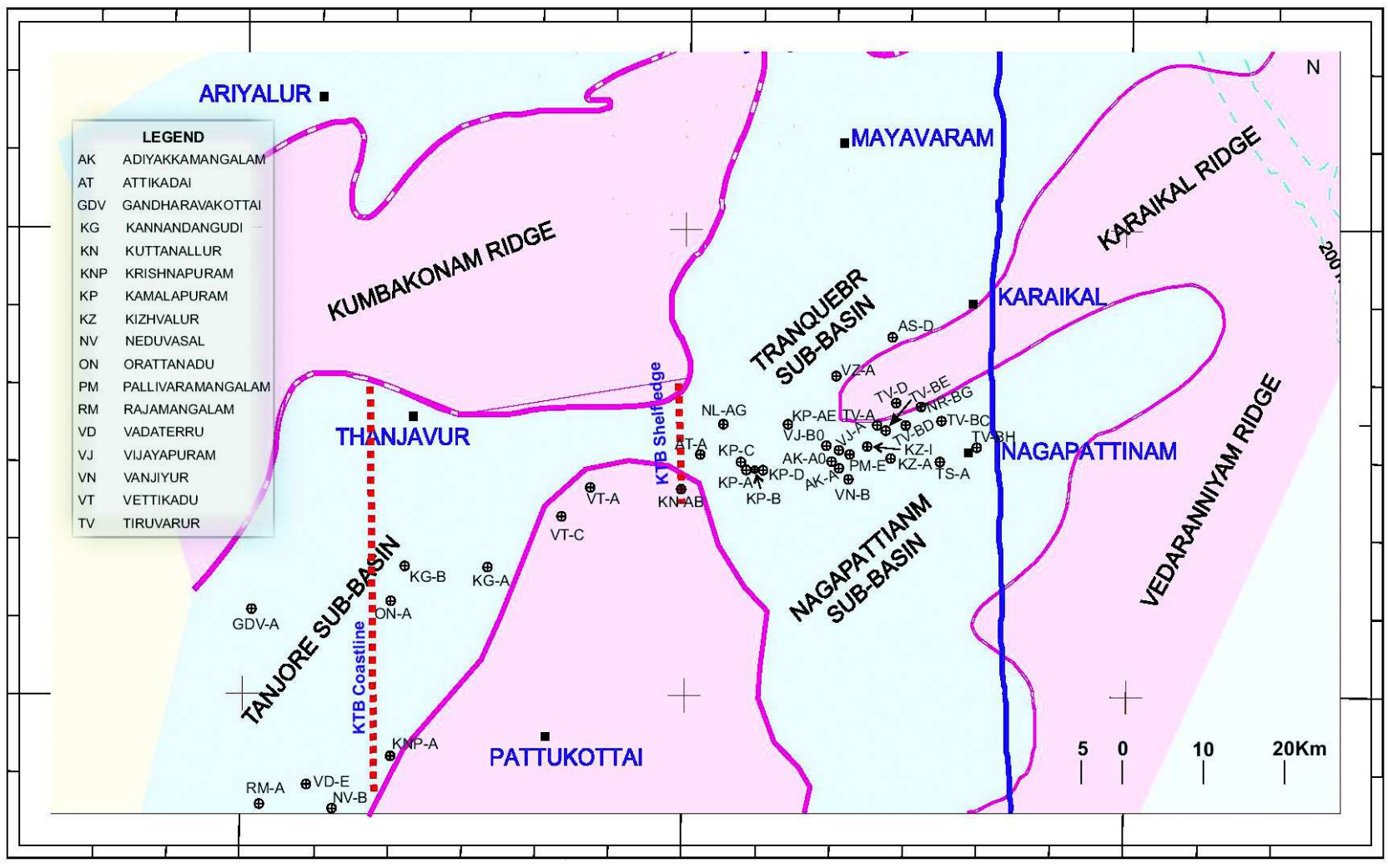

Fig. 7: Figure depicting the shoreline and shelf edge during KTB in the study area 


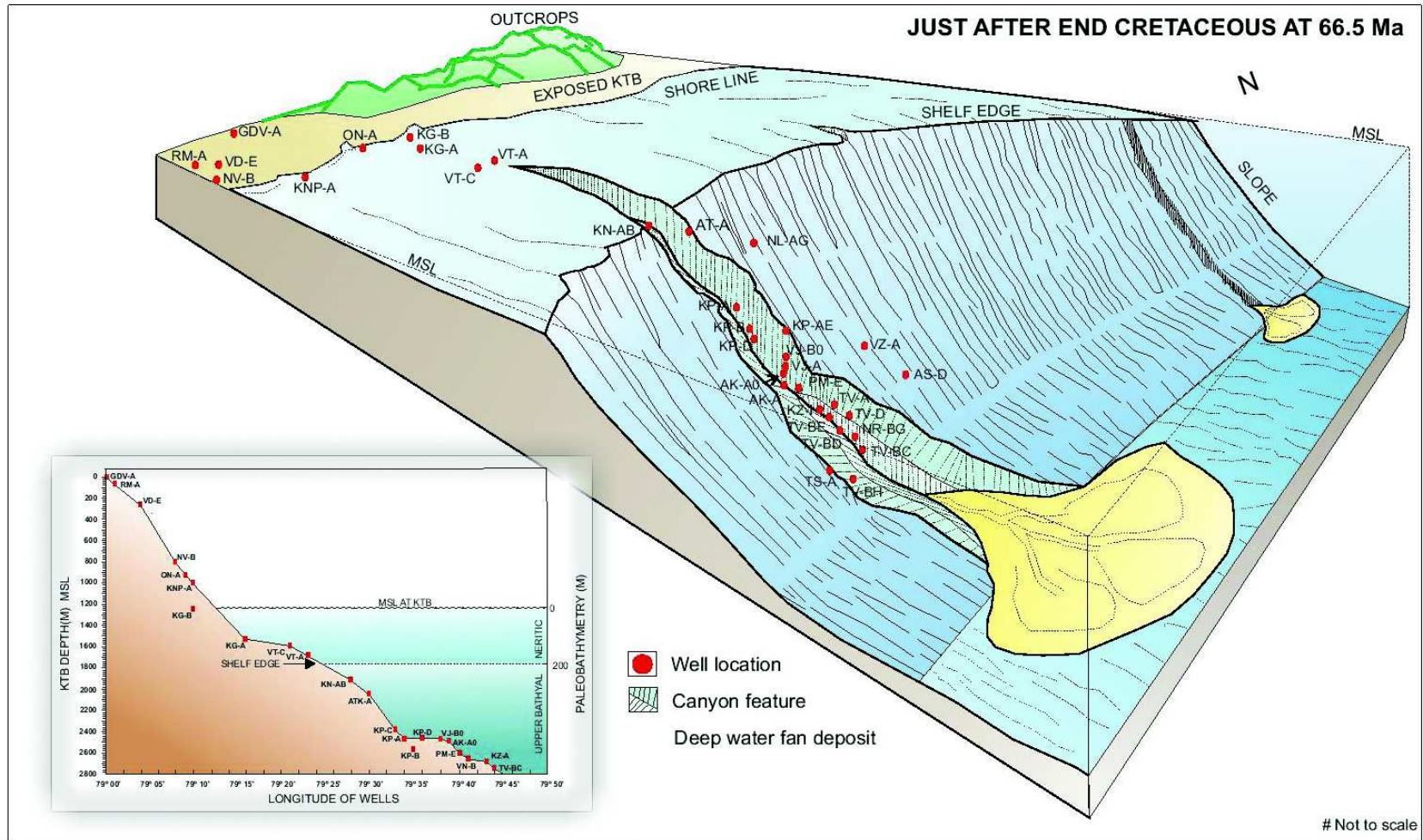

Fig. 8: The 3-dimensional block diagram depicting the KTB canyon in Nagapattinam sub-basin w.r.t basin floor profile. The figure depicts the migration of the shore line and shelf edge collapse resulting in the canyon formation. The inset figure gives the nature of the shelf-slope profile at KTB from west to east of the basin

Nannilam areas running along or parallel to Pattukottai - Kumbakonam highs (Fig. 7). The canyon alignment is almost perpendicular to the KTB shelf edge.

The doming of the west central and peninsular India continued till the base of planktic zone CF3 (67.2Ma). The continent ruptured and the Reunion hot mantle plume gushed out as the first phase of Deccan flood basalts (67.2-67 Ma). This was the period of basinal elevation and tilting creating instability across the shelf edge. The sedimentation process got disrupted. This basinal uplift continued till the second phase of Deccan flood basalts during planktic zones CF2-1 (66.4-66Ma). Between these two volcanic phases, a chain of sedimentary processes got initiated in the Nagapattinam subbasin with the critical point of shelf edge collapse coinciding with phase -2 Deccan volcanic event. This triggered slumping, sliding and debris flows creating the KTB canyon (Fig. 8). This continued till the end of phase - 3 Deccan event in the early part of planktic zone P1 (65.5$65.4 \mathrm{Ma})$. In the peripheral areas of canyon, the sedimentation resumed in zone P1 soon after the volcanism ended as a response to transgression caused by post volcanic thermal compression and subsidence. However, the canyon was active till zone P2 (62 Ma) and whatever sedimentation took place was removed. Preservation of sediments began from zone P2-P3 in the canyon. What appears at first sight to be a destructive tectonic phenomenon creating a huge canyon has turned out to be a major hydrocarbon reservoir habitat in the Nagapattinam subbasin of the Cauvery Basin.

\section{Acknowledgements}

The authors are highly grateful to Director (Exploration) for his permission to participate in IUGS activities and to publish this paper. The authors are thankful to Shri R K Khanna, ED-Basin Manager, Cauvery Basin for his constant encouragement. The authors are thankful to Mr. S Prabhakaran, GGM (Geology)-Block Manager II for suggesting this project and Dr. B G Goswami, GM-HRGL for extending facilities to carry out this work. The authors are thankful to Dr. A N Reddy, Chief Geologist (Rtd.) for critically reviewing the manuscript. 


\section{References}

Courtillot V E (1990) A volcanic eruption, Scientific America, October, 1990, 53-60

Jaiprakash B C, Singh J and Raju D S N (1993) Foraminiferal events across $\mathrm{K} / \mathrm{T}$ boundary and age of Deccan volcanism in Palakollu area, Krishna - Godavari basin, India Journ Geol Soc India 41 105-117

Keller G (1988) Extinction, Survivorship and evolution of planktonic foraminifera across Cretaceous-Tertiary boundary at El. Kef., Tunisia, Mar Micropal 13 239-263

Keller G, Bhowmick P K, Upadhyay H, Dave A, Reddy A N, Jaiprakash B C and Adatte A (2011) Deccan volcanism linked to the Cretaceous-Tertiary boundary mass extinction: New evidences from ONGC wells in the Krishna-Godavari Basin Jour Geol Soc India 78 399-428

Keller G, Adatte T, Bhowmick P K, Upadhyay J, Dave A, Reddy A N and Jaiprakash B C (2012) Nature and timing of extinctions in Cretaceous-Tertiary planktic foraminifera preserved in Deccan intertrappean sediments of the Krishna-Godavari Basin, India, Earth and Planetary Science Letters (Elsevier) 341-344 211-221

Keller G, Jaiprakash B C and Reddy A N (2016) Maastrichtian to Eocene Subsurface Stratigraphy of the Cauvery Basin and Correlation with Madagascar Jour Geol Soc India 87 5-34

Nagendra R, Bhavani R, Dinakaran V, Reddy A N and Jaiprakash B C (2001) Outcrop sequence stratigraphy of Kallankurchchi Formation of Velliperinjiam mine and its correlation with Tancem mine, Ariyalur Group, Tamilnadu Indian Jour Petr Geol 10 23-36

Nagendra R, Reddy A N, Jaiprakash B C and Bhavani R (2002) Outcrop sequence stratigraphy of the Maastrichtian Kallankurichhi Formation, Ariyalur Group, Tamilnadu Jour Geol Soc India 59 243-248
Nagendra R, Kamala Kannan B V, Gargi Sen, Harry Gilbert, Bakkiaraj D, Reddy A N and Jaiprakash B C (2011) Sequence surfaces and Paleobathymetric trends in Albian to Maastrichtian sediments of Ariyalur area, Cauvery basin, India, Marine and Petroleum Geology (Elsevier) 28 895905

Nagendra R, Sathiyamoorthy P and Reddy A N (2014) Foraminiferal Biostratigraphy and Paleobathymetric Trends across the Cretaceous - Tertiary in Neyveli Area, Cauvery Basin, India Stratigraphy and Geological Correlation 22 708-716

Raju D S N, Jaiprakash B C, Ravindran C N, Kalyansunder R and Ramesh P (1994) The magnitude of hiatus and sea level changes across K/T boundary in Cauvery and KrishnaGodavari Basins, India Jour Geol Soc India 44 301-315

Rangaraju M K, Abinash Agrawal and Prabhakar K N (1993) Tectono-Stratigraphy, Structural Styles, Evolutionary Model and Hydrocarbon Habitat, Cauvery and Palar Basins; Proc. $2^{\text {nd }}$ Seminar on Petroliferous Basins of India, S K Biswas et al. (eds.) Indian Petroleum Publishers, Dehradun 1371 396

Reddy A N, Jaiprakash B C, Rao M V, Chidambaram L and Bhaktavatsala K V (2013) Sequence Stratigraphy of Late Cretaceous Successions in the Ramnad Sub-basin, Cauvery Basin, India; In Proc. XXIII ICMS and International Symposium on Global Bioevents in Earth's History; Malarkodi, N., Keller G, Reddy A N and Jaiprakash B C (Editors), Geol Soc India Spl Publ 1 78-97

White R and McKenzie (1989) Magmatism at rift zones: The generation of volcanic continental margins and flood basalts Jour Geophy Res 94 7685-7729. 